\section{ECONOMICS}

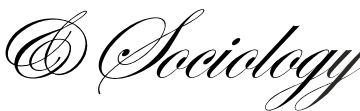

\author{
Anneli Kaasa, \\ University of Tartu, \\ Tartu, Estonia, \\ E-mail:anneli.kaasa@ut.ee
}

Received: March, 2016

1st Revision: September, 2016

Accepted: November, 2016

DOI: $10.14254 / 2071-$

789X.2016/9-4/1

JEL Classification: J24, O40, R11, K40
Kaasa, A. (2016), Social Capital, Institutional Quality and Productivity: Evidence from European Regions, Economics and Sociology, Vol. 9, No 4, pp. 11-26. DOI: 10.14254/2071-789X.2016/9-4/1

\title{
SOCIAL CAPITAL, INSTITUTIONAL QUALITY AND PRODUCTIVITY: EVIDENCE FROM EUROPEAN REGIONS
}

\begin{abstract}
This study investigates how institutional quality and different dimensions of social capital influence a region's labour productivity. As a novelty, regional-level data (80 regions of 24 European countries) were analysed and five different dimensions of social capital were included. Correlation and regression analysis were conducted. The results showed institutional trust and civic participation, which have not received much attention in the literature, to be the most important for productivity. Improving institutional quality would be helpful for productivity, but people's perception of institutional quality, trust in institutions and feeling of participation is even more important.
\end{abstract}

Keywords: productivity, social capital, institutional quality, Europe, regions.

\section{Introduction}

Productivity is undoubtedly one of the most important determinants of economic growth and the welfare of people. Hence, it is worthwhile to study the possible determinants of productivity. When looking at the determinants of productivity at the aggregate (country) level, the literature has mainly focussed on factors like human capital, $R \& D$, innovations showing positive links between these factors, productivity and economic growth. However, these factors seem to be insufficient for explaining differences in the levels of productivity in different countries (Sayes, 2011). Therefore, as also pointed out by Beugelsdijk and van Schaik (2005), the research has to go beyond these standard factors of productivity and explore other possible factors, such as social capital, e.g. trust and networks, and institutional quality covering the rule of law, political stability, regulatory quality or government effectiveness, for instance.

Although many authors have emphasised the importance of social capital or institutional quality for economic development, not much empirical research can be found on the relationships between those factors and productivity (Sharpe, 2004). Also, the research has mainly focussed on trust and networks in general, but no further investigation of various dimensions of social capital, such as institutional trust, civic participation, informal and formal networks as possible factors of productivity, can be found. Furthermore, it is reasonable to assume that there may also be significant within-country differences in the social and institutional environments which could influence productivity differences in 
different regions. However, most of the literature on productivity focusses on the country level analysis (Dettori et al., 2012; Artige and Nicolini, 2006). As a novelty, this article aims to address all the aforementioned gaps in the previous research.

The aim of the current study is to explore the possible impact of social capital and institutional quality on the productivity levels of European countries at the regional level. More specifically, labour productivity as the most widely used measure of productivity is viewed as a dependent variable. In addition to the standard factors of productivity, as control variables institutional quality and different dimensions of social capital, such as general trust, institutional trust, informal and formal networks, are considered.

The data for calculating labour productivity indicators as well as the data for the control variables came from Eurostat. The data for social capital came from the European Values Study (see EVS, 2010) and the European Social Survey (see ESS, 2008). Based on the initial indicators from these surveys, variables describing different components of social capital were created with the help of factor analysis. In order to describe different aspects of institutional quality, often the World Bank database of the Worldwide Governance Indicators (WGI) (The World Bank, 2014) is used. Lately, new data in the form of the European Quality of Government Index have become available that provide also regional-level estimates corrected for the regional differences (Charron et al., 2014). All these data sources enable to analyse European regions at the NUTS 1 level. The number of regions covered in this analysis was limited by the countries covered in the EVS and ESS as well as data availability for the regional-level estimates of the European Quality of Government Index. Altogether, 80 regions in 23 European countries are covered in this analysis. Correlation and regression analysis are used to examine the relationships of social capital and institutional quality with productivity.

This article is organised as follows. Section 1 presents the theoretical background and Section 2 introduces the data and operationalisation. Section 3 provides and Section 4 discusses the results. Section 5 summarises the article.

\section{Theoretical background}

There are various ways to define productivity (see, for example, Tangen, 2005). In this article, productivity is understood as efficiency in production: the relation of output to input which can be expressed as an output-input ratio (Syverson, 2011). In the case of this kind of a definition, the most widely used measure of productivity is labour productivity, although sometimes capital or materials productivity are also used (Syverson, 2011; OECD, 2001; Sharpe, 2004). At that, it has to be borne in mind that labour productivity as an output-input ratio does not reflect only the productivity of labour in terms of the capacities or efforts of the workers, but also, for instance, the availability and using intensity of other production factors or technical change (OECD, 2001; Sharpe, 2004). Hence, in a sense, labour productivity actually reflects the impact of all factors that affect productivity (Sharpe, 2004). An alternative measure that is also often used is multi-factor productivity, also known as total factor productivity (TFP), which shows the change in output that is not explained by the change in the observable outputs like labour or capital (Syverson, 2011; OECD, 2001). Although the indicators of labour productivity and TFP may often show the same trends, their different nature has to be taken into account as a possible explanation for somewhat different empirical results. Productivity can be viewed at the firm level or at the aggregate (country, regional) level. In this article, the aggregate level productivity is analysed.

Regarding possible factors influencing productivity, innovation has been viewed as and confirmed to be crucial for productivity (Crespi and Zuñiga, 2010; Peters et al., 2003; Hall, 2011; Sayes, 2011; Isaksson, 2007; Sharpe, 2004). Applying technological advances enables to use production factors more effectively. Therefore, most studies of the drivers of 
productivity have included innovation and new technology in one or another form. Another factor that is often analysed is R\&D. For creating and applying new technologies, R\&D is very important, leading to new ideas and also forming an absorptive capacity for using new ideas. R\&D has been shown to be positively related to productivity (Crespi and Zuñiga, 2010; Griffith et al., 2004; Syverson, 2011; Isaksson, 2007).

Next, human capital is also considered as an important factor of productivity. Human capital has often been included into the analysis when studying determinants of productivity and a positive relationship with productivity has been shown (Gorodnichenko and Roland, 2010; Yamamura and Shin, 2012; Ghulam, 2012; Sharpe, 2004; Isaksson, 2007). The level of human capital determines the quality of the labour force. Well-educated workers are more likely to effectively use other production factors, develop and apply new ideas. Education determines the economy's capacity to carry out technological innovations as well as the socalled absorptive capacity: the ability to adopt technologies that have been created and are already used by others (Isaksson, 2007; Sharpe, 2004; Ghulam, 2012).

One of the factors that should additionally be considered as possibly influencing productivity is social capital. Social capital is a complex concept with many dimensions and there are many definitions of social capital; Adler and Kwon (2002) and Tamaschke (2003), for example, provide exhaustive overviews of different definitions. Social capital can also be studied at both the individual and aggregate (country, regional) level. At the aggregate level, according to Putnam (1995), social capital 'refers to features of social organization such as networks, norms, and social trust that facilitate coordination and cooperation for mutual benefit'. When analysing the impact of social capital on economic growth, innovation, or productivity, two important aspects of social capital that are analysed are networks and trust, or more broadly: the structural and cognitive dimensions of social capital (Dakhli and de Clercq, 2004; Knack and Keefer, 1997; Landry et al., 2002; Heliwell, 1996; Casey and Christ, 2005; Beugelsdijk and van Schaik, 2005; Jankauskas and Šeputienė, 2007). The aggregate level productivity derives from the productivity of firms. Previous studies have shown that firm performance is closely related to the social capital of individuals working in firms (Burt, 2000). The social capital of those individuals, in turn, is strongly interrelated with and can be aggregated to the society-level social capital of a country or a region (van Oorshot and Arts, 2005). Hence, the social capital of a region can be viewed as a proxy for the social capital of the individuals working for the firms in that particular region.

The influence of social capital on productivity can be described as creating a favourable environment for economic performance. The most mentioned aspect here is that social capital - trust and networks - foster the diffusion of information and knowledge (Jankauskas and Šeputienè, 2007; Sabatini, 2008; Yamamura and Shin, 2012; Di Guilmi et al., 2008; Grafton et al., 2004; Beugelsdijk and van Schaik, 2005) not only among the workers of the same firm, but also through the professional networks and relationships with friends and former colleagues, for example. These ties enable to lower the cost and time of information search and exchange as well as allow to adopt new innovations earlier (Iyer et al., 2005). Hence, in this sense social capital also contributes to the economy's absorptive capacity which is very important for productivity (Isaksson, 2007). Trust also encourages cooperation between firms and hence allows a more effective use of resources (Bjørnskov and Méon, 2010; Beugelsdijk and van Schaik, 2005). Networks are claimed to have a synergy effect, bringing together skills and different ideas which may lead to radical breakthroughs remarkably improving productivity (Subramaniam and Youndt, 2005; Kaasa, 2009). Next, in a trusting environment workers tend to be more relaxed and motivated to do their best, thus improving productivity (Jankauskas and Šeputienè, 2007; Sabatini, 2008; Di Guilmi et al., 2008). Also, social networks may bring along more control among colleagues and a higher quality of the effort made (Sabatini, 2008; Di Guilmi et al., 2008). Social capital has been 
claimed to lower uncertainty and the transaction costs (Beugelsdijk and van Schaik, 2005; Bjørnskov and Méon, 2010; Lekovic, 2012; Jankauskas and Šeputiené, 2007): trust within social networks serves as a substitute for a legal system, for example in contract monitoring and enforcement. When fewer resources have to be used for securing individuals and firms from theft and other dishonest practices, more resources can be devoted to production and improving technology. This also means that investment decisions can be made using a longer time horizon and it is possible to invest into riskier, but eventually more productive projects (Bjørnskov and Méon, 2010).

Unfortunately, there are only a few studies that have empirically tested the impact of social capital on productivity at the society level. Jankauskas and Šeputienè (2007) found both trust and networks to have a remarkable positive relationship with labour productivity using a sample of 23 European countries. At the same time, civism did not correlate with labour productivity in their analysis. Knack and Keefer (1997) analysed the data of 29 countries and found trust to be significantly positively correlated with output per worker, while the correlation with the TFP was positive, but insignificant. Casey and Christ (2005) studied the states of the US and concluded there not to be any significant relationship between productivity and different social capital indicators. In a study of 67 countries by Bjørnskov and Méon (2010), the social trust indicator appeared to have a strong positive association with the TFP. Of course, there are also studies at the firm level that may help to shed some light on the possible relationships at the society level. For example, Lall and Ghosh (2002) analysed Mexican firms and confirmed a positive relationship between productivity and both formal and informal networks. In a study of Italian firms by Sabatini (2008), formal networks appeared to be positively and informal networks to be negatively related to productivity. Hence, the empirical evidence concerning social capital and productivity is scarce and mixed.

In addition, the institutional environment should be considered as an important factor for productivity (Islam, 2008; Lio and Liu, 2008; Ghulam, 2012). There are many definitions of institutional quality, also often referred to as governance or governance quality (Kaufmann et al., 2010; UNPAN, 2007). This article draws on the approach of Kaufmann et al. (2010) which seeks to find a compromise between the broader and narrower definitions and defines governance as the traditions and institutions by which authority in a country is exercised. It can also be viewed as the nature of the legal and political systems (Islam, 2008), including for example the quality of public services, the trustworthiness of the legal system, control of corruption, but also political stability and possibilities for civic participation.

Regarding the impact of institutional quality on productivity, institutions are first of all expected to lower the transaction costs by securing property rights and enforcing contracts (Lio and Liu, 2008; Jankauskas and Šeputienè, 2007; Bjørnskov and Méon, 2010). Wellfunctioning institutions enable firms to spend more on production and improving technology, and less on monitoring and securing. Problems, such as corruption, in turn, may provide incentives to divert resources from productive activities to rent-seeking and dishonest practices (Bjørnskov and Méon, 2010). In this sense, institutional quality and social capital may be viewed as substitutes of each other (Jankauskas and Šeputienè, 2007): when there is less social capital, institutional quality should be better for keeping the transaction costs low; and when institutions perform poorly, social capital may be of great help. However, often a higher level of institutional quality is associated with the higher level of social capital (Iyer et al., 2005). Institutions have also been viewed as being important in enhancing learning and spreading knowledge, because leaving the provision of education and information to the private sector may not reach the social optimum (Isaksson, 2007).

The empirical evidence addressing the impact of institutional quality on productivity mostly supports these theoretical considerations (Isaksson, 2007). For example, Jankauskas and Šeputienè (2007) analysed the data of 23 European countries and found different 
governance indicators to be positively and significantly related to labour productivity. Ghulam (2012) studied 14 Asian countries and found government effectiveness and regulatory quality to be positively related to the average labour productivity. In a study of 67 countries by Bjørnskov and Méon (2010), the legal quality and democracy indicator appeared to have a positive association with the TFP. Hall and Jones (1999), after analysing 127 countries, concluded that differences in institutions and government policies are related to differences in the output per worker. In an analysis of 22 OECD countries, Salinas-Jiménez and Salinas-Jiménez (2006) showed different corruption indicators to be negatively related to the GDP per worker. Hence, the empirical evidence is much clearer in the case of institutional quality than in the case of social capital as a potential factor of productivity.

\section{Data and operationalisation}

This study analyses the data of European regions on the NUTS 1 level. The NUTS Nomenclature of Territorial Units for Statistics - is a widely used hierarchical classification of regions within countries established by Eurostat (see European Commission. Eurostat, 2012). This classification subdivides each country (NUTS 0 level) into one or more NUTS 1 regions, each of which, in turn, can be subdivided into one or more NUTS 2 regions and so on. At the NUTS 1 and NUTS 2 levels, countries are divided into regions based on administrative divisions as well as the lower and upper limits for the population size for each level. The NUTS 1 level was chosen in order to capture possible regional differences; data at the NUTS 2 level were not available for most of indicators used here.

For measuring the aggregate level productivity of a particular region, in this article labour productivity as the most widely used measure of productivity was chosen. As the output indicator of labour productivity (as an output-input ratio), the GDP is the most available and employed indicator (see, for example, Jankauskas and Šeputienè, 2007; Casey and Christ, 2005; Salinas-Jiménez and Salinas-Jiménez, 2006). For the current analysis, two indicators were retrieved from Eurostat (2014): the GDP at current market prices in euros, and in order to take possible differences in purchasing power into account, the GDP at current market prices in the Purchasing Power Standard (PPS) per inhabitant. Regarding the input indicator of labour productivity, both the number of workers and the number of work hours can be chosen. In previous studies, mostly productivity per worker has been used (Jankauskas and Šeputienè, 2007; Knack and Keefer, 1997; Hall and Jones, 1999; Ghulam, 2012; SalinasJiménez and Salinas-Jiménez, 2006; Casey and Christ, 2005). However, simply counting the workers does not take into account possible part-time workers or overtime, nor the differences in the statutory work week in different countries (OECD, 2001). Hence, for comparison purposes, in this article two measures obtained from Eurostat (2014) are used: the number of employees, and the hours actually worked by the employees per year. All these indicators pertain to the year 2008. By combining these different input and output indicators, four different labour productivity indicators were computed. The correlation coefficients between these four productivity indicators can be seen in Appendix Table A1. Since all the correlations are over 0.90 , no significant differences can be assumed.

The data about social capital stem from two databases: the European Values Study (EVS) and the European Social Survey (ESS), which among others include various questions enabling to describe social capital. The ESS (see ESS, 2008) is a biennial multi-country survey covering an increasing number of European countries. The first round was conducted in 2002 and this article uses the fourth wave (year 2008) data, as for this year data from the EVS were available as well. The EVS (see EVS, 2010) is a multi-country survey that is repeated every nine years and covers also an increasing number of European countries. Here, the fourth wave (year 2008) is used. There are usually 1,000 to 2,000 respondents per country 
in the case of the EVS and 1,500 to 2,500 respondents per country in the case of the ESS. Also, both surveys provide weights in order to ensure that the regional-level data would be representative of the demographic structure of a country. This offers a good basis for combining these two surveys. As one example, Akçomak and ter Weel (2009) used these surveys for analysing social capital. Both surveys enable to analyse the regional level as well, since they include respondents from various regions of a particular country. In the regions at the NUTS1 level used in this article, the number of respondents per region was 562.96 on average in the ESS and ranged from 21 to 2,367; in the EVS, the number of respondents per region was 545.74 on average and ranged from 20 to 1,793. The regional-level indicators corresponding to each question used in this article were obtained by aggregating individuallevel data using the weights provided by the ESS and EVS. It has to be mentioned that the number of respondents was quite small in some regions. However, because of the complex character of the concept of social capital, surveys are the best option available for measuring social capital and the weighted ESS and EVS data are the best proxy for different dimensions of social capital in European regions at present.

Social capital is often divided into two forms or types: cognitive and structural. Two dimensions of the cognitive social capital and three dimensions of the structural social capital are covered. Among the cognitive social capital, general trust is described by two indicators (one from the ESS and one from the EVS), while institutional trust is described by five indicators (three from the ESS and two from the EVS). The aim was to include similar questions from both surveys, when available, in order to smooth possible differences in the two surveys. Regarding the structural social capital, informal networks were described by two indicators from the ESS and by one from the EVS. In the case of formal networks, only two indicators could be used from the EVS and none from the ESS. Last, civic participation is again described by five indicators (two from the ESS and three from the EVS). All indicators used can be seen in Appendix Table A2. In order to capture the information of initial indicators into corresponding dimensions, a confirmatory factor analysis (the principal components method) was performed separately for each dimension of social capital. The factor loadings, percentages of total variance explained by the factor, and the Kaiser-MeyerOlkin (KMO) measures indicating the appropriateness of the factor model are presented in Appendix Table A2. The shares of total variance explained and the KMO measures can be viewed as acceptable (values of the $\mathrm{KMO}$ measure larger than 0.6 or 0.5 are usually considered as acceptable; in the case of only two indicators, the KMO value is always 0.5 because of the formula used for calculating the KMO measure). The factor scores of the new latent variables were saved as variables.

The data about institutional quality were drawn from a newly available database offering the European Quality of Government Index (EQGI) (Charron et al., 2014). This regional-level index was calculated by taking the national level indices of governance from the WGI (The World Bank, 2014) which is based on expert assessment, and correcting these indices by survey data reflecting the experiences and perceptions of citizens at the regional level. The governance index of WGI (also used, for example, by Jankauskas and Šeputienè, 2007) is based on six sub-indices: the rule of law, control of corruption, government effectiveness, political stability, regulatory quality, voice and accountability (see Kaufmann et al., 2010 or The World Bank, 2014 for further information). The EQGI pertaining to the year 2010 was used as the closest to the year 2008 for which other indicators of the current study were available. As the state of institutional quality does not change rapidly, it can be assumed that the results are not drastically influenced by this lag. For some countries, the EQGI was available at the NUTS 2 level and not at the NUTS 1 level. In those cases, the indicator for a particular NUTS 1 region was calculated as a weighted average of the NUTS 2 regions 
pertaining to that NUTS 1 region (the data about the population of different regions provided by the same database were used as weights).

As control variables, the indicators reflecting innovation, $R \& D$, and education were used. As a proxy for innovative activities an indicator of patent applications to the EPO by priority year (per million of labour force) was used. R\&D activities were described by an indicator of total R\&D personnel and researchers (as a percentage of the active population, full time equivalent). (An indicator of R\&D expenditures per inhabitant was considered as an alternative, but the indicator of R\&D personnel was chosen because of a stronger logical connection with labour productivity. The correlation coefficient of the two R\&D indicators was 0.92; therefore, no remarkable differences are to be expected.) The education level of a population in a particular region was measured by the percentage of the population aged 2564 with tertiary education attainment. All these indicators pertain to the year 2008 and were drawn from Eurostat (2014).

The number of regions covered in this analysis was limited by the countries covered in the EVS and ESS as well as data availability for the regional-level estimates of the European Quality of Government Index. Altogether, 80 regions in 23 European countries (Belgium, Bulgaria, Croatia, the Czech Republic, Cyprus, Denmark, Estonia, Finland, France, Germany, Hungary, Ireland, Latvia, Lithuania, Netherlands, Poland, Portugal, Romania, Slovakia, Slovenia, Spain, Sweden, the United Kingdom) are covered in this analysis.

\section{Results}

First, correlation analysis between the productivity indicators and various factors of productivity was conducted. The correlation coefficients are presented in Table 1. As it can be seen from Table 1, almost all factors have a statistically significant positive relationship with all of the indicators of labour productivity. The relationship seems to be the strongest in the case of institutional trust and civic participation, followed by the quality of government. The relationship is remarkably weaker in the case of formal networks, even being statistically insignificant with one productivity indicator. Also, the effect of all factors seems to be larger when the GDP in euros is used and somewhat smaller when the GDP in PPS is used. This is logical as taking the purchasing power into account usually reduces the differences between the so-called wealthier and poorer countries and regions.

Table 1. Correlation coefficients between the factors of labour productivity and various productivity indicators

\begin{tabular}{lllll}
\hline & $\begin{array}{l}\text { GDP (EUR)/ } \\
\text { employees }\end{array}$ & $\begin{array}{l}\text { GDP (EUR)/ } \\
\text { hours worked }\end{array}$ & $\begin{array}{l}\text { GDP (PPS)/ } \\
\text { employees }\end{array}$ & $\begin{array}{l}\text { GDP (PPS)/ } \\
\text { hours worked }\end{array}$ \\
\hline Patenting & $0.55^{* * *}$ & $0.61^{* * *}$ & $0.43^{* * *}$ & $0.54^{* * *}$ \\
\hline R\&D & $0.58^{* * *}$ & $0.58^{* * *}$ & $0.48^{* * *}$ & $0.50^{* * *}$ \\
\hline Tertiary education & $0.54^{* * *}$ & $0.50^{* * *}$ & $0.43^{* * *}$ & $0.40^{* * *}$ \\
\hline General trust & $0.52^{* * *}$ & $0.53^{* * *}$ & $0.36^{* * *}$ & $0.42^{* * *}$ \\
\hline Institutional trust & $0.74^{* * *}$ & $0.74^{* * *}$ & $0.61^{* * *}$ & $0.64^{* * *}$ \\
\hline Informal networks & $0.57^{* * *}$ & $0.54^{* * *}$ & $0.46^{* * *}$ & $0.45^{* * *}$ \\
\hline Formal networks & $0.30^{* * *}$ & $0.38^{* * *}$ & 0.18 & $0.30^{* * *}$ \\
\hline Civic participation & $0.74^{* * *}$ & $0.74^{* * *}$ & $0.60^{* * *}$ & $0.64^{* * *}$ \\
\hline Quality of government & $0.67^{* * *}$ & $0.66^{* * *}$ & $0.47^{* * *}$ & $0.53^{* * *}$ \\
\hline
\end{tabular}

*** significant at the 0.01 level, ** significant at the 0.05 level, * significant at the 0.10 level.

Next, regression analysis was used in order to shed more light on these relationships. As it can be assumed and also seen from Appendix Table A3, all the productivity factors 
included into the analysis are moderately or strongly correlated to each other. Regarding possible multi-collinearity, the VIF values ranged from 1.59 to 4.40 , being lower than the lowest commonly suggested limit: 5 (although limits such as 8 or 10 are also often used). The often-used strategy to capture the strongly related factors into fewer variables with the help of factor analysis was not used here, because the aim here was to analyse different dimensions of social capital separately, and institutional quality separately from the social capital. Using just one indicator of social capital, for example, would indicate a strong relationship of social capital with productivity indicators, but would provide little information about the importance of the different dimensions of social capital. However, it is clear that the regression coefficients may still be influenced by the strong relationships. In order to investigate the possible influence, a factor covering all social capital dimensions was constructed and used in the regression analysis instead of separate social capital dimensions. It appeared that the extent, sign and significance of the regression coefficients of other factors were not remarkably influenced by this change.

The results of the regression analysis for four different indicators of labour productivity are presented in Tables 2-5. For all models, the p-value of the F-statistic was below 0.001 . The values of the adjusted R-square increased when explanatory variables were added and these values were somewhat lower when the GDP in PPS was used, as it could be expected considering the lower correlation coefficients in the case of the GDP in PPS shown in Table 1.

First, only control variables were included to the regression (Model 1) and in this case, regression coefficients of patenting and the share of population with tertiary education were positive and statistically significant for all productivity indicators. The share of those dealing with R\&D did not appear to have a statistically significant relationship with any productivity indicators. Then, the index of government quality was added (Model 2) and it appeared that after this addition, education became insignificant in all cases and patenting in the cases where the number of employees was used as an input for the productivity indicator. This can be explained with the possibility that in those regions where the values of the patenting indicator are higher (those regions are usually also wealthier), the productivity per an hour worked is relatively higher than the productivity per worker; hence, in those regions the number of hours worked per worker seems to be smaller on average. However, in the next specifications the patenting indicator became insignificant for all productivity indicators.

Table 2. Standardised regression coefficients of the factors of GDP (EUR)/ employees

\begin{tabular}{lllll}
\hline & Model 1 & Model 2 & Model 3 & Model 4 \\
\hline Patenting & $0.38^{* * *}$ & 0.15 & 0.07 & 0.07 \\
\hline R\&D & 0.08 & 0.18 & 0.07 & 0.07 \\
\hline Tertiary education & $0.36^{* * *}$ & 0.14 & 0.10 & 0.10 \\
\hline General trust & & & -0.11 & -0.11 \\
\hline Institutional trust & & $0.43^{* * *}$ & $0.42^{* * *}$ \\
\hline Informal networks & & 0.07 & 0.07 \\
\hline Formal networks & & -0.02 & -0.02 \\
\hline Civic participation & & $0.34^{* * *}$ & $0.34^{* * *}$ \\
\hline Quality of government & & $0.43^{* * *}$ & & 0.01 \\
\hline adjusted R Square & 0.45 & 0.52 & 0.63 & 0.67 \\
\hline F-statistic & $19.87^{* * *}$ & $21.64^{* * *}$ & $17.22^{* * *}$ & $15.09^{* * *}$ \\
\hline
\end{tabular}

$* * *$ significant at the 0.01 level, $* *$ significant at the 0.05 level, $*$ significant at the 0.10 level. 
Table 3. Standardised regression coefficients of the factors of GDP (EUR)/ hours worked

\begin{tabular}{|c|c|c|c|c|}
\hline & Model 1 & Model 2 & Model 3 & Model 4 \\
\hline Patenting & $0.49 * * *$ & $0.28 * * *$ & 0.18 & 0.19 \\
\hline $\mathrm{R} \& \mathrm{D}$ & 0.01 & 0.10 & -0.01 & -0.02 \\
\hline Tertiary education & $0.32 * * *$ & 0.12 & 0.08 & 0.08 \\
\hline General trust & & & -0.09 & -0.08 \\
\hline Institutional trust & & & $0.36^{* * *}$ & $0.37 * * *$ \\
\hline Informal networks & & & -0.01 & 0.00 \\
\hline Formal networks & & & 0.07 & 0.07 \\
\hline Civic participation & & & $0.40 * * *$ & $0.41^{* * *}$ \\
\hline Quality of government & & $0.39 * * *$ & & -0.04 \\
\hline adjusted R Square & 0.47 & 0.55 & 0.68 & 0.68 \\
\hline F-statistic & $21.73 * * *$ & $22.55 * * *$ & $17.88 * * *$ & $15.68 * * *$ \\
\hline
\end{tabular}

*** significant at the 0.01 level, ${ }^{* *}$ significant at the 0.05 level, $*$ significant at the 0.10 level.

Table 4. Standardised regression coefficients of the factors of GDP (PPS)/ employees

\begin{tabular}{lllll}
\hline & Model 1 & Model 2 & Model 3 & Model 4 \\
\hline Patenting & $0.25^{*}$ & 0.12 & -0.01 & 0.02 \\
\hline R\&D & 0.13 & 0.19 & 0.17 & 0.11 \\
\hline Tertiary education & $0.25^{*}$ & 0.13 & 0.03 & 0.05 \\
\hline General trust & & & -0.23 & -0.18 \\
\hline Institutional trust & & & $0.49^{* * *}$ & $0.57^{* * *}$ \\
\hline Informal networks & & & 0.11 & 0.16 \\
\hline Formal networks & & & -0.08 & -0.08 \\
\hline Civic participation & & & 0.22 & $0.28^{* * *}$ \\
\hline Quality of government & & $0.25^{* * *}$ & & -0.23 \\
\hline adjusted R Square & 0.28 & 0.31 & 0.47 & 0.48 \\
\hline F-statistic & $9.43^{* * *}$ & $8.14^{* * *}$ & $7.55^{* * *}$ & $6.93^{* * *}$ \\
\hline
\end{tabular}

*** significant at the 0.01 level, ${ }^{* *}$ significant at the 0.05 level, $*$ significant at the 0.10 level.

Table 5. Standardised regression coefficients of the factors of GDP (PPS)/ hours worked

\begin{tabular}{lllll}
\hline & Model 1 & Model 2 & Model 3 & Model 4 \\
\hline Patenting & $0.45^{* * *}$ & $0.31^{* * *}$ & 0.18 & 0.21 \\
\hline R\&D & 0.03 & 0.08 & 0.03 & -0.02 \\
\hline Tertiary education & $0.24^{*}$ & 0.11 & 0.04 & 0.06 \\
\hline General trust & & & -0.16 & -0.12 \\
\hline Institutional trust & & & $0.37^{* * *}$ & $0.43^{* * *}$ \\
\hline Informal networks & & & 0.00 & 0.04 \\
\hline Formal networks & & & 0.04 & 0.05 \\
\hline Civic participation & & & $0.33^{* * *}$ & $0.38^{* * *}$ \\
\hline Quality of government & & $0.26^{* * *}$ & & -0.19 \\
\hline adjusted R Square & 0.35 & 0.39 & 0.52 & 0.52 \\
\hline F-statistic & $13.28^{* * *}$ & $11.43^{* * *}$ & $9.01^{* * *}$ & $8.15^{* * *}$ \\
\hline
\end{tabular}

*** significant at the 0.01 level, ${ }^{* *}$ significant at the 0.05 level, * significant at the 0.10 level.

Model 3 includes all five dimensions of social capital instead of the institutional quality indicator. Here, no control variables appeared to be significant and among social capital dimensions, institutional trust and civic participation turned out to have statistically significant positive coefficients. The only exception is when the GDP (PPS) per employee 
was used as a productivity indicator. In that case, civic participation did not appear to be statistically significant. Finally, all mentioned variables were entered into the regression analysis (Model 4). The results regarding the control variables and social capital remained the same: only institutional trust and civic participation appeared to be statistically significant and both of them are positively related to labour productivity. The regression coefficient of civic participation in the case of the GDP (PPS) per employee had also become statistically significant. In addition, it can be seen from Tables 2-5 that after including social capital into the regression, the regression coefficients of government quality became insignificant. This allows to assume that the indicators of institutional trust and civic participation capture the sources of labour productivity better than the index of government quality.

\section{Discussion}

The results of this article provide significant support for the argument that social capital influences productivity indeed, but the findings also indicate that some dimensions of social capital seem to be more important for productivity than others. The results of the regression analysis showed institutional trust and civic participation to have a strong positive relationship with labour productivity and when these variables were entered into the analysis, all other variables turned out to be statistically insignificant. Taking into account the strong relationships between all factors included into this analysis, this does not mean, of course, that technological development or education are not important at all. The results should be viewed rather as indicating the relative importance of different factors. Both institutional trust and civic participation reflect the relationship of an individual with the state and institutions. When people have higher trust for formal institutions, they tend to have more motivation to participate in social processes as they believe that their voice will be heard and considered. Furthermore, when people participate in social processes, they may feel more like a part of the system and may have more trust in institutions. Statistically significant positive regression coefficients of institutional trust and civic participation show that they serve, indeed, as a substitute or supplement for a legal system lowering uncertainty and transaction costs, as also noted by Beugelsdijk and van Schaik (2005); Bjørnskov and Méon, 2010; Lekovic (2012) and Jankauskas and Šeputienè (2007). A secure and stable environment where people and firms feel protected from possible dishonest practices or abrupt changes seems to be most important for high productivity.

Institutional trust and institutional quality are related in the same way as general trust and trustworthiness: trustworthiness creates trust and trust reflects trustworthiness. Institutional trust reflects in a way people's perceptions of institutional quality: in the case of high institutional quality, institutional trust can be expected to be high as well (here, the correlation coefficient was 0.80 , significant at the 0.01 level). Hence, it is very logical that the results showed high correlations between the quality of government indicator and productivity indicators, confirming the results of Jankauskas and Šeputiene (2007) (who also used correlation analysis), Ghulam (2012) or Hall and Jones (1999). Also, when social capital dimensions were not included into the regression, government quality appeared to have a statistically significant positive relationship with productivity. However, when social capital dimensions and government quality were both entered into the regression analysis, only the regression coefficients of institutional trust and civic participation turned out to be statistically significant. This can be explained by the possibility that what people think of institutions is more important than the objective expert-assessed state of institutions. Although the indicator of the European Quality of Government Index (Charron et al., 2014) used in this study incorporates also people's perceptions from a survey, the expert-assessed national level indices of governance serve as the basis. The indicator of institutional trust, however, reflects 
only people's perceptions. Hence, how people perceive institutional quality and how much trust they have in institutions is very important.

According to the correlation analysis, general trust and informal networks also have a remarkable positive relationship with labour productivity. Thus, it cannot be ruled out that trust and networks form a favourable environment for information diffusion or exchange and the synergy of ideas as well as a more trusting environment relaxing and motivating the workers. However, it seems that a secure and stable environment is even more important. This may also be related to the claim of Bjørnskov and Méon (2010) that trust influences productivity through its impact on the institutional quality. Last, formal networks appeared to be much less correlated with productivity than informal networks, indicating that activity in formal organisations and official memberships may be less important than direct relationships with other people.

With regard to policy implications, this article enables to shed light on the relative effect of different dimensions of social capital. As institutional trust and civic participation appeared to be the most important social capital dimensions for labour productivity, focussing on these dimensions seems to be logical. Improving institutional quality is naturally important, but giving people information about those improvements and encouraging participation in the process of developing the improvements may significantly help to foster productivity.

Regarding the limitations of this study, it should be kept in mind that data sources focussing on Europe were used and European regions were analysed. Therefore, conclusions can be drawn for European regions only. Whether the analysed relationships can apply to the whole world is a topic for future studies when data for a sample larger than Europe become available. Also, data were not available for regions in all European countries in the ESS and EVS, therefore when more complete data become available, it would be interesting to re-run the analysis.

\section{Conclusions}

This article investigated the impact of institutional quality and different dimensions of social capital on labour productivity at the society level. As a novelty, the analysis was conducted at the regional level and besides the indicator of institutional quality, five different dimensions of social capital were included. The data of 80 regions from 24 European countries were analysed. First, factor analysis was used to capture the information of many initial indicators into variables describing different social capital dimensions. Then, correlation and regression analysis was performed, also including control variables describing patenting, $\mathrm{R} \& \mathrm{D}$ activities and the level of education. For comparison purposes, four differently calculated productivity indicators were used.

In the correlation analysis, all factors appeared to have a moderate or strong positive and statistically significant relationship with all productivity indicators. However, the regression analysis showed that after entering the social capital indicators into the model, all control variables turned out to be insignificant. Additionally, although the indicator of government quality appeared to have a statistically significant positive regression coefficient when added to the control variables, it lost its significance after the social capital indicators were also added. Among the social capital indicators, only institutional trust and civic participation, which have not received much attention in the literature so far, had statistically significant regression coefficients. These results of the regression analysis can be interpreted as showing the relative importance of different factors of productivity. All results were proved to remain the same for all four indicators of labour productivity used in this article. 
Hence, the results indicate that a secure and stable environment where people and firms trust institutions, feel protected and participate in social processes seems to be the most important for high productivity. Furthermore, it seems that the way in which people perceive institutional quality and how much trust they have in institutions is even more important than the objective state of institutional quality. Thus, regarding the implications of this study, if one would intend to increase productivity in a region, improving institutional quality would be helpful, but it is even more important to ensure that the people affected would be aware of and believe in those improvements.

\section{Acknowledgements}

This work was supported by the institutional research funding IUT 20-49 of the Estonian Ministry of Education and Research.

\section{References}

Adler, P. S., Kwon, S.-W. (2002), Social capital: prospects for a new concept, Academy of Management Review, Vol. 27, pp. 17-40.

Akçomak, S., ter Weel, B. (2009), Social capital, innovation and growth: Evidence from Europe, European Economic Review, Vol. 53, No. 5, pp. 544-567.

Artige, L., Nicolini, R. (2006), Labor productivity in Europe: Evidence from a sample of regions, CREPP Working Paper, No. 2006/08.

Beugelsdijk, S., van Schaik, T. (2005), Social capital and growth in European regions: an empirical test, European Journal of Political Economy, Vol. 21, pp. 301-324.

Bjørnskov, C., Méon, P.-G. (2010), The Productivity of Trust, Centre Emile Bernheim Working Paper, No. 10/042.

Burt, R. S. (2000), The networks structure of social capital, In: Staw, B. M., Sutton, R. I. (Eds.), Research in Organisational Behavior, Vol. 22, pp. 345-423.

Casey, T., Christ, K. (2005), Social Capital and Economic Performance in the American States, Social Science Quarterly, Vol. 86, No. 4, pp. 826-845.

Charron, N., Dijkstra, L., Lapuente, V. (2014), Regional Governance Matters: Quality of Government within European Union Member States, Regional Studies, Vol. 48, No. 1, pp. 68-90.

Crespi, G., Zuñiga, P. (2010), Innovation and Productivity: Evidence from Six Latin American Countries, IDB Working Paper Series, No. IDB-WP-218.

Dakhli, M., de Clercq, D. (2004), Human capital, social capital, and innovation: a multicountry study, Entrepreneurship and Regional Development, Vol. 16, pp. 107-128.

Dettori, B., Marrocu, E., Paci, R. (2012), Total Factor Productivity, Intangible Assets and Spatial Dependence in the European Regions, Regional Studies, Vol. 46, Special Issue: Intangible Assets and Regional Economic Growth, pp. 1401-1416.

Di Guilmi, C., Clementi, F., Di Matteo, T., Gallegati, M. (2008), Social networks and labour productivity in Europe: an empirical investigation, Journal of Economic Interaction and Coordination, Vol. 3, pp. 43-57.

ESS (2008), ESS Round 4: European Social Survey Round 4 Data (2008). Data file edition 4.0. Norwegian Social Science Data Services, Norway - Data Archive and distributor of ESS data.

European Commission. Eurostat (2012), NUTS - Nomenclature of territorial units for statistics. Introduction, http://epp.eurostat.ec.europa.eu/ portal/page/portal/ nuts_nomenclature/ introduction (referred on 24/09/2013). 
Eurostat (2014), Database, http://epp.eurostat.ec.europa.eu/portal/page/ portal/eurostat/ home/ (referred on 05/01/2014).

EVS (2010), European Values Study 2008, 4th wave, Integrated Dataset, GESIS Data Archive, Cologne, Germany, ZA4800 Data File Version 2.0.0 (2010-11-30).

Ghulam, M. (2012), Human Capital, Governance and Productivity in Asian Economies, Job Market Paper, https://editorialexpress.com/cgi-bin/conference/download.cgi?db_name= res_phd_2013\&paper_id=213 (referred on 19/11/2014).

Gorodnichenko, Y., Roland, G. (2010), Culture, Institutions and the Wealth of Nations, NBER Working Paper Series, No. 16368.

Grafton, R. Q., Kompas, T., Owen, P. D. (2004), Productivity, factor accumulation and social networks: theory and evidence, Australian National University, Economics and Environment Network Working Paper, No. EEN0401.

Griffith, R., Redding, S., Van Reenen, J. (2004), Mapping the Two Faces of R\&D: Productivity Growth in a Panel of OECD Industries, The Review of Economics and Statistics, Vol. 86, No. 4, pp. 883-895.

Hall, B. H. (2011), Innovation and Productivity, NBER Working Paper Series, No. 17178.

Hall, R. E., Jones, C. I. (1999), Why do Some Countries Produce So Much More Output Per Worker than Others? Quarterly Journal of Economics, Vol. 114, No. 1, pp. 83-116.

Heliwell, J. F. (1996), Economic Growth and Social Capital in Asia, NBER Working Paper Series, No. 5470.

Isaksson, A. (2007), Determinants of total factor productivity: a literature review, UNIDO Research and Statistics Branch Staff Working Paper, No. 02/2007.

Islam, N. (2008), Determinants of Productivity across Countries: An Exploratory Analysis, The Journal of Developing Areas, Vol. 42, No. 1, pp. 201-242.

Iyer, S., Kitson, M., Toh, B. (2005), Social Capital, Economic Growth and Regional Development, Regional Studies, Vol. 39, No. 8, pp. 1015-1040.

Jankauskas, V., Šeputienè, J. (2007), The Relation between Social Capital, Governance and Economic Performance in Europe, Business: Theory and Practice, Vol. VIII, No. 3, pp. 131-138.

Kaasa, A. (2009), Effects of Different Dimensions of Social Capital on Innovative Activity: Evidence from Europe at the Regional Level, Technovation, Vol. 29, No. 3, pp. 218233.

Kaufmann, D., Kraay, A. and Mastruzzi, M. (2010), The Worldwide Governance Indicators: Methodology and Analytical Issues (September 2010), World Bank Policy Research Working Paper, No. 5430.

Knack, S., Keefer, P. (1997), Does social capital have an economic payoff? A cross-country investigation, Quarterly Journal of Economics, Vol. 112, pp. 1251-1288.

Lall, S. V., Ghosh, S. (2002), Learning by Dining: Informal Networks and Productivity in Mexican Industry, World Bank Policy Research Working Paper, No. 2789.

Landry, R., Amara, N., Lamari, M. (2002), Does social capital determine innovation? To what extent? Technological Forecasting and Social Change, Vol. 69, pp. 681-701.

Lekovic, V. (2012), Trust as an Institutional Factor of Economic Success, Economic Horizons, Vol. 14, No. 2, pp. 65-78.

Lio, M., Liu, M.-C. (2008), Governance and agricultural productivity: A cross-national analysis, Food Policy, Vol. 33, pp. 504-512.

OECD (2001), Measuring Productivity: Measurement of Aggregate and Industry-Level Productivity Growth, OECD Manual, http://www.oecd.org/std/productivitystats/2352458.pdf (referred on 25/01/2014).

Peters, B., Lööf, H., Janz, N. (2003), Firm Level Innovation and Productivity: Is there a Common Story Across Countries? ZEW Discussion Papers, No. 03-26. 
Putnam, R. (1995), Bowling alone: Americas declining social capital, Journal of Democracy, Vol. 6, No. 65-78.

Sabatini, F. (2008), Does Social Capital Improve Labour Productivity in Small and Medium Enterprises? International Journal of Management and Decision Making, Special Issue on Social Capital and Organisations, Vol. 9, No. 5, pp. 454-480.

Salinas-Jiménez, M. D. M., Salinas-Jiménez, J. (2006), Corruption and Productivity Growth in OECD Countries, ERSA conference papers, No. ersa06p99.

Sayes, E. (2011), Economic and Social Determinants of Productivity; Balancing Economic and Social Explanations, paper presented at the Sociological Association of Aotearoa (NZ) Annual Conference 2011.

Sharpe, A. (2004), Exploring the Linkages between Productivity and Social Development in Market Economies, Centre for the Study of Living Standards, CSLS Research Report, No. 2004-02.

Subramaniam, M., Youndt, M. A. (2005), The influence of intellectual capital on the types of innovative capabilities, Academy of Management Journal, Vol. 48, pp. 450-463.

Syverson, C. (2011), What Determines Productivity? Journal of Economic Literature, Vol. 49, No. 2, pp. 326-365.

Tamaschke, L. (2003), The role of social capital in regional technological innovation: seeing both the wood and the trees, In: Huysman, M., Wenger, E., Wulf, W. (Eds.), Communities and Technologies, Kluwer BV, Deventer.

Tangen, S. (2005), Demystifying productivity and performance, International Journal of Productivity and Performance Management, Vol. 54, No. 1, pp. 34-46.

The World Bank (2014), Worldwide Governance Indicators, http://info.worldbank.org/governance/wgi/index.aspx\#home (referred on 08/08/2015).

UNPAN (2007), Public Governance Indicators. A Literature Review, Department of Economic and Social Affairs, New York: UNPAN, http://unpan1.un.org/ intradoc/groups/public/documents/un/unpan027075.pdf (referred on 06/07/2015).

van Oorshot, W., Arts, W. (2005), Social capital of European welfare states: the crowding out hypothesis revisited, Journal of European Social Policy, Vol. 15, pp. 5-26.

Yamamura, E., Shin, I. (2012), Heterogeneity, Trust, Human Capital and Productivity Growth: Decomposition Analysis, Journal of Economics and Econometrics, Vol. 55, No. 2, pp. 51-77. 


\section{Appendix}

Table A1. Correlation coefficients of various indicators of labour productivity

\begin{tabular}{|c|c|c|c|c|}
\hline & $\begin{array}{l}\text { GDP (EUR)/ } \\
\text { employees }\end{array}$ & $\begin{array}{l}\text { GDP (EUR)/ } \\
\text { hours worked }\end{array}$ & $\begin{array}{l}\text { GDP (PPS)/ } \\
\text { employees }\end{array}$ & $\begin{array}{l}\text { GDP (PPS)/ } \\
\text { hours worked }\end{array}$ \\
\hline GDP (EUR)/ employees & 1 & $0.98 * * *$ & $0.95 * * *$ & $0.94 * * *$ \\
\hline GDP (EUR)/ hours worked & & 1 & $0.92 * * *$ & $0.97 * * *$ \\
\hline GDP (PPS)/ employees & & & 1 & $0.96 * * *$ \\
\hline GDP (PPS)/ hours worked & & & & 1 \\
\hline
\end{tabular}

*** significant at the 0.01 level, ${ }^{* *}$ significant at the 0.05 level, ${ }^{*}$ significant at the 0.10 level.

Table A2. Results of the confirmatory factor analyses for social capital dimensions

\begin{tabular}{|c|c|c|c|c|}
\hline $\begin{array}{c}\text { Latent } \\
\text { variable }\end{array}$ & Indicators & $\begin{array}{l}\text { Factor } \\
\text { loadings }\end{array}$ & $\begin{array}{c}\text { Variance } \\
\text { explained } \\
(\%) \\
\end{array}$ & $\begin{array}{c}\text { KMO Measure } \\
\text { of Sampling } \\
\text { Adequacy }\end{array}$ \\
\hline \multirow{2}{*}{ General trust } & $\begin{array}{l}\text { People can be trusted/can't be too careful } \\
\text { share of "people can be trusted" (EVS) }\end{array}$ & 0.93 & \multirow{2}{*}{86.07} & \multirow{2}{*}{0.50} \\
\hline & $\begin{array}{l}\text { Most people can be trusted or you can't be too } \\
\text { careful, scale } 0-10 \text { (ESS) }\end{array}$ & 0.93 & & \\
\hline \multirow{5}{*}{$\begin{array}{l}\text { Institutional } \\
\text { trust }\end{array}$} & Trust in the legal system, scale $0-10$ (ESS) & 0.93 & \multirow{5}{*}{75.29} & \multirow{5}{*}{0.71} \\
\hline & Trust in country's parliament, scale $0-10$ (ESS) & 0.91 & & \\
\hline & Trust in the police, scale $0-10$ (ESS) & 0.91 & & \\
\hline & $\begin{array}{l}\text { How much confidence in: the police, scale 1-4 } \\
\text { (EVS) }\end{array}$ & 0.85 & & \\
\hline & $\begin{array}{l}\text { How much confidence in: parliament, scale 1-4 } \\
\text { (EVS) }\end{array}$ & 0.74 & & \\
\hline \multirow{3}{*}{$\begin{array}{l}\text { Informal } \\
\text { networks }\end{array}$} & $\begin{array}{l}\text { Anyone to discuss intimate and personal } \\
\text { matters with, share of those who have (ESS) }\end{array}$ & 0.79 & \multirow{3}{*}{60.46} & \multirow{3}{*}{0.66} \\
\hline & $\begin{array}{l}\text { How important in your life: friends and } \\
\text { acquaintances, scale 1-4 (EVS) }\end{array}$ & 0.78 & & \\
\hline & $\begin{array}{l}\text { How often socially meet with friends, relatives } \\
\text { or colleagues, scale 1-7 (ESS) }\end{array}$ & 0.76 & & \\
\hline \multirow{2}{*}{$\begin{array}{l}\text { Formal } \\
\text { networks }\end{array}$} & $\begin{array}{l}\text { Do you work unpaid for: average number of } \\
\text { organisations mentioned, max } 14 \text { (EVS) }\end{array}$ & 0.97 & \multirow{2}{*}{93.80} & \multirow{2}{*}{0.50} \\
\hline & $\begin{array}{l}\text { Do you belong to: average number of } \\
\text { organisations mentioned, max } 14 \text { (EVS) }\end{array}$ & 0.97 & & \\
\hline \multirow{5}{*}{$\begin{array}{l}\text { Civic } \\
\text { participation }\end{array}$} & Signing a petition, scale 1-3 (EVS) & 0.92 & \multirow{5}{*}{64.82} & \multirow{5}{*}{0.67} \\
\hline & Joining in boycotts, scale 1-3 (EVS) & 0.85 & & \\
\hline & $\begin{array}{l}\text { Signed petition last } 12 \text { months, share of those } \\
\text { who did (ESS) }\end{array}$ & 0.83 & & \\
\hline & $\begin{array}{l}\text { Attending lawful demonstrations, scale 1-3 } \\
\text { (EVS) }\end{array}$ & 0.81 & & \\
\hline & $\begin{array}{l}\text { Taken part in lawful public demonstration last } \\
12 \text { months, share of those who did (ESS) }\end{array}$ & 0.57 & & \\
\hline
\end{tabular}


Table A3. Correlation coefficients of various factors of productivity

\begin{tabular}{|c|c|c|c|c|c|c|c|c|c|}
\hline & 1. & 2. & 3. & 4. & 5. & 6. & 7. & 8. & 9. \\
\hline 1. Patenting & 1 & $0.71 * * *$ & $0.34 * * *$ & $0.52 * * *$ & $0.60 * * *$ & $0.44 * * *$ & $0.41 * * *$ & $0.54 * * *$ & $0.56^{* * *}$ \\
\hline 2. $\mathrm{R} \& \mathrm{D}$ & & 1 & $0.66^{* * *}$ & $0.60 * * *$ & $0.53 * * *$ & $0.48^{* * *}$ & $0.25 * *$ & $0.63 * * *$ & $0.50 * * *$ \\
\hline 3. Tertiary education & & & 1 & $0.55 * * *$ & $0.52 * * *$ & $0.56^{* * *}$ & $0.26 * *$ & $0.53 * * *$ & $0.54 * * *$ \\
\hline 4. General trust & & & & 1 & $0.69 * * *$ & $0.60 * * *$ & $0.52 * * *$ & $0.53 * * *$ & $0.70 * * *$ \\
\hline 5. Institutional trust & & & & & 1 & $0.58 * * *$ & $0.48^{* * *}$ & $0.67 * * *$ & $0.80^{* * *}$ \\
\hline 6. Informal networks & & & & & & 1 & $0.37 * * *$ & $0.62 * * *$ & $0.70^{* * *}$ \\
\hline 7. Formal networks & & & & & & & 1 & $0.24 * *$ & $0.45^{* * *}$ \\
\hline 8. Civic participation & & & & & & & & 1 & $0.71 * * *$ \\
\hline $\begin{array}{l}\text { 9. Quality of } \\
\text { government }\end{array}$ & & & & & & & & & 1 \\
\hline
\end{tabular}

